\title{
CONSTRUÇÃO DE VETORES DE EXPRESSÃO PARA OS GENES E6 E E7 DE HPV-16 EM ESCHERICHIA COLI
}

\author{
A. C. da SILVA $^{1}$, L. S. de MACÊDO ${ }^{1}$, G. H. de A. CARDOZO ${ }^{1}$, A. J. D. SILVA ${ }^{1}$, A. C. de \\ FREITAS $^{1}$ \\ ${ }^{1}$ Universidade Federal de Pernambuco, Centro de Biociências, Departamento de Genética \\ E-mail para contato: anacris1723@hotmail.com
}

\begin{abstract}
RESUMO - O Papilomavirus humano (HPV) é um vírus de tamanho pequeno, capsídeo icosaédrico, não envelopado e com DNA circular de fita dupla que apresenta tropismo pelo epitélio humano. É reconhecido que a infecção persistente por HPVs de alto risco é a principal causa do câncer de colo uterino. Este trabalho tem como objetivo principal produzir as proteínas E6 e E7 de HPV-16 em Escherichia coli para posteriormente conseguir a possível validação dos efeitos de vacina de DNA no combate ao HPV. A oncoproteína E6 é alvo para imunização genética, principalmente porque induz a formação de um complexo trimérico com a proteina p53, promovendo a degradação proteolítica desta última na célula o que impede suas atividades regulatórias sobre o ciclo celular. Enquanto que a oncoproteína E7 é importante por sua habilidade de se ligar e promover a degradação via proteossomo de membros da familia $R b$. Os genes de interesse foram clonados e expressos no vetor $p A E$, este possui significantes vantagens como o tamanho pequeno (2822pb), expressão de cauda de histidina (6XHIS) N-terminal e produz alto número de cópias de plasmídeo por célula. Os genes de interesse E6 e E7 apresentam 489pb e 309pb, respectivamente e, na ocasião, foram adicionados os terminais de restrição XhoI e EcoRI que são sítios de restrição também presentes no vetor pAE, o que permitiu a devida inserção do inserto no vetor. A clonagem foi confirmada por técnica de PCR, e em seguida foi feita indução da expressão por IPTG. Ensaios posteriores serão necessários para confirmar a produção das proteinas.
\end{abstract}

Palavras-chave: HPV, câncer cervical, vacina, expressão.

\begin{abstract}
Human Papillomavirus (HPV) is a small virus, icosahedral, nonenveloped capsid and double-stranded circular DNA that is tropism by the human epithelium. It is recognized that persistent infection by high-risk HPVs is the leading cause of cervical cancer. This work aims to produce the E6 and E7 proteins of HPV16 in Escherichia coli to later achieve the possible validation of the effects of DNA vaccine in the fight against HPV. The E6 oncoprotein is a target for genetic immunization, mainly because it induces the formation of a trimeric complex with the p53 protein, promoting proteolytic degradation of the latter in the cell, which impedes its regulatory activities on the cell cycle. While the E7 oncoprotein is important for its ability to bind and promote degradation via proteasomes of members of the Rb family. The genes of interest were cloned and expressed in the pAE vector, which has significant advantages such as small size (2822pb), N-
\end{abstract}


terminal histidine (6XHIS) tail expression and produces high number of plasmid copies per cell. The genes of interest E6 and E7 present 489bp and 309bp, respectively, and, at the time, the restriction sites XhoI and EcoRI which are restriction sites were also present in the $\mathrm{pAE}$ vector, which allowed proper insertion of the insert into the vector. Cloning was confirmed by PCR technique, and then IPTG expression was induced. Further tests will be needed to confirm the production of the proteins.

Key-words: HPV, cervical cancer, vaccine, expression.

\section{INTRODUÇÃO}

O câncer cervical é o terceiro tumor mais frequente entre mulheres e seu desenvolvimento está associado à infecção pelo Papilomavírus Humano (HPV). O HPV tipo 16 corresponde a $57 \%$ dos casos diagnosticados e a vacinação é vista como uma medida de combate (ESTIMATIVA INCA, 2016).

Existem no país duas vacinas profiláticas: uma bi e outra quadrivalente, baseadas em VLPs (partículas semelhantes a vírus) da proteína estrutural L1, devidamente aprovadas e registradas pela ANVISA. A vacina quadrivalente abrange os tipos 6, 11, 16 e 18 e foi implementada no SUS pelo Ministério da Saúde. No entanto, apesar de ambas terem demonstrado eficácia na prevenção da infecção por HPV, nenhuma apresenta efeitos terapêuticos para infecções pré-estabelecidas. Ou seja, tais vacinas têm utilidade quando administradas a mulheres num período anterior ao contato com o vírus, mas mulheres que já apresentam lesões não são beneficiadas. Portanto, estratégias vacinais alternativas se fazem necessárias (CUTTS et al., 2007).

Vacinas de DNA têm um custo relativamente mais baixo se comparados a outros tipos de vacinas e são um pouco mais simples de serem produzidas. Para a validação dessas vacinas faz-se necessário a produção da proteína recombinante de modo que ela seja utilizada como parâmetro de comparação nos ensaios de imunização, além de servir como antígeno para detecção de anticorpos no ELISA. Sistemas de expressão heteróloga procariotos, como Escherichia coli, permitem a produção dessas proteínas recombinantes e são vantajosos por apresentarem um baixo custo aliado a um alto rendimento protéico (GOOPAL \& KUMAR, 2013).

Diante do exposto, este trabalho visa a produção das proteínas E6 e E7 de HPV16, em Escherichia coli. Tais proteínas serão utilizadas em testes de validação de vacinas de DNA baseada nos referidos genes.

\section{MATERIAIS E MÉTODOS}

Materiais: Vetor O vetor pAE (RAMOS et al., 2004) foi utilizado para clonar os genes de interesse. O tamanho pequeno e o alto número de cópias facilita a clonagem e expressão dos genes.

\section{Métodos}

Mediante uma análise prévia dos sítios de restrição do vetor pAE, as enzimas de restrição mais adequadas para se trabalhar foram XhoI e EcoRI. Os genes E6 e E7 foram digeridos, purificados diretamente do tubo de microcentrífuga e submetidos à reação de ligação sob a ação da enzima T4 DNA ligase (Promega ${ }^{\mathrm{TM}}$ ). Os plasmídeos resultantes da 
reação foram utilizados como agente transformante para Escherichia coli (Top10), conforme metodologia de clonagem molecular descrita por Sambrook et al. 2001.

Após a transformação, os repiques resultantes que apresentaram melhor crescimento foram selecionados para análise através de mini extração plasmidial descrita por Maniatis et al (1989). Foi realizado inóculo de $5 \mathrm{~mL}$ em meio de cultura LB acrescido de ampicilina a partir dos repiques, permanecendo incubados a $37^{\circ} \mathrm{C}$ por $16 \mathrm{~h}$ sob agitação. Após esse período, $1,5 \mathrm{~mL}$ da cultura foi transferido para tubo de microcentrífuga, ao que se seguiu uma série de centrifugações, acompanhadas da adição de soluções para promover lise celular e precipitação de proteínas e DNA genômico. $\mathrm{O}$ material resultante da extração foi analisado quanto à composição plasmidial por meio da Reação em Cadeia Polimerase (PCR) e visualizado por meio de gel de agarose $1 \%$.

\section{RESULTADOS E DISCUSSÃO}

Após os procedimentos de clonagem molecular, foi feita uma PCR para a confirmação da produção do plasmídeo com a construção pAEE6 e pAEE7. É possível evidenciar a banda na altura esperada de E6 e E7, 489pb e 309pb, respectivamente.

Figura 1: Clonagem molecular de E6 e E7 de HPV-16 em vetor pAE; Eletroforese em gel de agarose a 1\% em tampão TAE; M - marcador Ladder GeneRuler 1kb ThermoScientific; 1 a 6 PCR com fragmento de 489pb correspondendo ao gene E6 HPV-16; 7 a 11 - PCR com fragmento de 309pb correspondendo ao gene E7 HPV-16; 12 - Controle negativo da PCR.

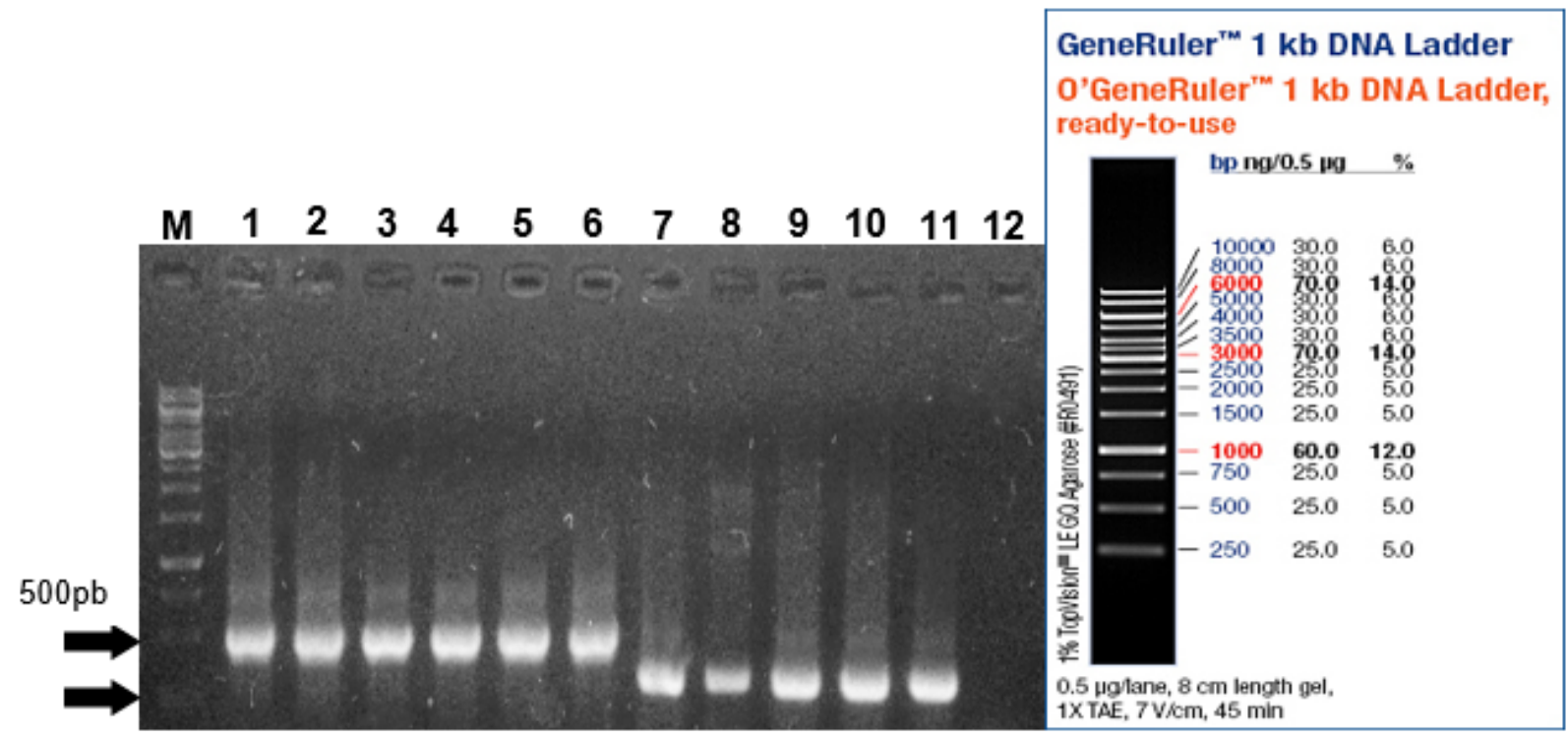

$250 \mathrm{pb}$

\section{CONCLUSÃO}

Vacinas terapêuticas baseadas em oncogenes de HPV vêm sendo testadas, com graus variados de sucesso. Até o presente momento, nenhuma estratégia vacinal foi totalmente eficaz contra o câncer cervical. Os resultados obtidos ainda aguardam para poder confirmar a produção das proteínas E6 e E7 de HPV-16, que são importantes para serem usados na validação dos efeitos de vacinas de DNA contra o HPV-16 e também sua utilização como controle em estudos funcionais com polimorfismos. Até o presente momento, não foi possível confirmar a produção por meio de imunodetecção de forma que mais testes confirmatórios devem ser realizados. A proteína purificada poderá ser 
utilizada posteriormente em ensaios imunológicos utilizando E6 e E7 como alvos terapêuticos.

\section{REFERÊNCIAS}

CORDEIRO, M.N.; PAOLINI, F.; MASSA, S.; CURZIO, G.; ILLIANO, E.; SILVA, A.J.D.; FRANCONI, R.; BISSA, M.; MORGHEN, C.M.; FREITAS, A.C.; VENUTI, A. Anti-tumor effects of genetic vaccines against HPV major oncogenes. Human Vac. \& Immunotherap. 11:1-8, 2015.

CUTTS, F.T.; FRANCESCHI, S.; GOLDIE, S.; CASTELLSAGUE, X.; DE SANJOSE, S.; GARNETT G.; EDMUNDS, W.J.; CLAYES, P. Human papillomavirus and HPV vaccines: a review. Bulletin of the World Health Organization 85:719-726, 2017.

DOORBAR J.; QUINT W.; BANKS L.; BRAVO I.G.; STOLER M.; BROKER T.R.; STANLEY M.A. The biology and life-cycle of human papillomaviruse. Vaccine. v. 30 (5) p. $55-70,2012$.

KAWANA, K.; ADACHI, K.; KOJIMA, S.; KOZUMA, S.E.; FUJII, T. Therapeutic human papillomavirus (HPV) vaccines: a novel approach. The Open Virology Journal 6:264-269, 2012.

ESTIMATIVA 2016: INCIDÊNCIA DE CÂNCER NO BRASIL. Instituto Nacional De Câncer José Alencar Gomes Da Silva (INCA)/ Ministério da Saúde, Coordenação Geral de Ações Estratégicas, Coordenação de Prevenção e Vigilância. - Rio de Janeiro: INCA, 2016. 126 p., ISBN 978-85-7318-284-2.

RAMOS C.R.R.; ABREU, P.A.E. A high-copy T7 Escherichia coli expression vector for the production of recombinant proteins with a minimal N-terminal His-tagged fusion peptide. Brazilian Journal of Medical and Biological Research, 37: 1103-1109. 2004.

SAMBROOK, J.; FRITSCH, E.F.; MANIATIS, T. Molecular cloning: a laboratory manual. 2. ed. New York: Cold Spring Harbor Laboratory Press, 800 p, 1989.

\section{AGRADECIMENTOS}

CAPES, FACEPE e CNPq. 